ISSN 0103-5150

Fisioter. Mov., Curitiba, v. 29, n. 2, p. 343-350, Apr./June 2016

Licenciado sob uma Licença Creative Commons DOI: http://dx.doi.org.10.1590/0103-5150.029.002.A013

\title{
Functional capacity, pulmonary and respiratory muscle strength in individuals undergoing hemodialysis
}

\author{
Capacidade funcional, pulmonar e força muscular \\ respiratória de indivíduos submetidos à hemodiálise
}

\section{Simone Regina Posser, Sheila Cristina Cecagno-Zanini, Fabiana Piovesan, Camila Pereira Leguisamo*}

Universidade de Passo Fundo (UPF), Passo Fundo, RS, Brazil

\begin{abstract}
Introduction: Individuals with chronic kidney disease (CKD) undergoing hemodialysis (HD) present low cardiorespiratory fitness and functional capacity. Metabolic changes, due to the disease, can result in a variety of pathophysiological conditions that favor the development of respiratory muscle weakness. However, very little is known about the performance of the respiratory muscles and the influence of HD on them. Aim: To evaluate and correlate pulmonary function, functional capacity and respiratory muscle strength in patients with CKD undergoing HD. Methods: Cross-sectional study comprising 23 patients with CKD, that met the following inclusion criteria: patients of both genders, who perform HD three times a week for a minimum period of three months. Respiratory muscle strength was evaluated using a respiratory pressure meter, lung function through spirometry and functional capacity through the 6-minute walk test (6MWT) before the HD session. Results: All patients were male and mean age was $50.2 \pm 15.8$ years. The median duration of HD was 3 (1.5 to 6.0) years. The mean values obtained in comparison to those predicted were MIP\% $36.0 \pm 13.6$, MEP\% $49.5 \pm 15.8$, FVC\% 93.8 \pm 21.1 , FEV1\% $93.7 \pm 21.1$, FVC/VEF1\% $104.1 \pm 10.3$, and
\end{abstract}

*SRP: MSc, e-mail: si_posser@yahoo.com.br SCCZ: MSc, e-mail: sheilacecagno@hotmail.com FP: Doctoral student, e-mail: fabianapiovesan@hotmail.com CPL: PhD, e-mail: camila@upf.br 
6MWT\% $66.33 \pm 20.53$. A statistically significant positive correlation was observed between the 6MWT and MIP $(r=.63, p=.001)$ and MEP $(r=.67, p<.001)$, between the MIP and MEP $(r=.79, p<.001)$ and between the FEV1 and FVC $(r=.91, p<.001)$. Conclusion: Patients with CKD undergoing HD present changes in respiratory muscle strength, with the predicted values decreasing for age and gender, as well as the distance covered in the 6MWT, although, with normal spirometric values. Functional capacity was dependent on respiratory muscle strength, as well as the values of MIP and MEP, and the values of FVC and FEV1.

Keywords: Chronic kidney failure. Renal dialysis. Spirometry. Muscle strength. Physical fitness.

\section{Resumo}

Introdução: Indivíduos com doença renal crônica (DRC) submetidos a hemodiálise (HD) apresentam baixa capacidade cardiorrespiratória e funcional. As alterações metabólicas, devido a patologia, podem resultar em uma variedade de condições fisiopatológicas que favorecem o desenvolvimento de fraqueza muscular respiratória. No entanto, muito pouco é conhecido sobre o desempenho dos músculos respiratórios e a influência da HD sobre eles. Objetivo: Avaliar e correlacionar à função pulmonar, a capacidade funcional e a força muscular respiratória em pacientes com DRC submetidos à HD. Materiais e métodos: Estudo transversal composto por 23 pacientes com DRC, que se enquadravam nos seguintes critérios de inclusão: pacientes de ambos os sexos, que realizam HD três vezes por semana, por um período mínimo de três meses. Foi avaliada a força muscular respiratória através de manovuometria, função pulmonar por espirometria e a capacidade funcional pelo teste de caminhada dos 6 minutos (TC6) antes da sessão de HD. Resultados: Todos pacientes eram do sexo masculino e idade média de 50,2 $\pm 15,8$ anos. $O$ tempo mediano de HD era $3(1,5-6,0)$ anos. Os valores médios alca-

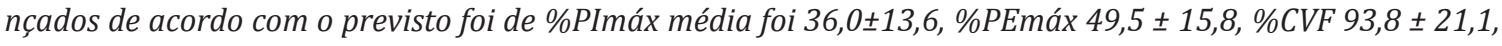
\%VEF1 93,7 $\pm 21,1, \%$ CVF/VEF1 104,1 $\pm 10,3$, \%TC6 66,33 $\pm 20,53$. Observou-se correlação estatisticamente significativa, positiva, entre o TC6 e PImáx ( $r=0,63, p=0,001)$, PEmáx $(r=0,67, p<0,001)$ e entre PImax e PEmax $(r=0,79, p<0,001)$ e VEF1 e CVF $(r=0,91, p<0,001)$. Conclusão: Indivíduos portadores de DRC em HD sofrem alterações na força muscular respiratória, com diminuição dos valores previstos para sexo e idade, assim como na distância percorrida no TC6, porém, com os valores espirométricos dentro da normalidade. A capacidade funcional mostrou-se dependente da força muscular respiratória, assim como os valores entre PImáx e PEmáx e VEF1 e CVF.

Palavras-chave: Falência renal crônica. Diálise renal. Espirometria. Força muscular. Aptidão física.

\section{Introduction}

The increasing incidence of chronic diseases in the population is a known fact and has led to much discussion about the issue. Noncommunicable diseases are the leading cause of death in the world, accounting for $63 \%$ of the 57 million deaths that occurred in 2008 , with the majority of these deaths (36 million) being assigned to cardiovascular diseases and diabetes, cancers and chronic respiratory diseases (1).

Chronic kidney disease (CKD) has received increasing attention from the international scientific community, with its high prevalence having been demonstrated in recent studies (2). This disease may be associated with hypertension, diabetes mellitus, as well as complications of the cardiopulmonary, cardiovascular and other systems: nervous, respiratory, musculoskeletal, immune, and endocrine/metabolic (2-4).

One of the main treatments for CKD is hemodialysis (HD), which is a therapeutic process capable of removing catabolites from the body and correcting the modifications of the internal environment, by means of circulating the blood through equipment appropriate for this purpose. Patients with CKD undergoing HD present impaired quality of life, due to limited cardiorespiratory fitness and decreased functional capacity which may impair performance in leisure activities, work and social life (5-8).

The evaluation of the strength, endurance and resistance to fatigue of the respiratory muscles allows significant indices of pulmonary function (PF), functional capacity $(\mathrm{FC})$ and respiratory muscle strength 
(RMS) to be obtained. Chronic kidney disease and its metabolic changes may result in a variety of pathophysiological conditions that favor the development of respiratory muscle weakness, however, very little is known about the performance of the respiratory muscles and the influence of HD on them $(8,9)$.

The aim of this study was to evaluate and correlate the PF, the FC and the RMS in CKD patients undergoing hemodialysis.

\section{Materials and methods}

This transversal and descriptive study was performed in an HD reference sector of a large hospital in the city of Passo Fundo-RS. The sample consisted of 23 patients with CKD that fulfilled the following inclusion criteria: patients of both genders, who had performed HD three times a week for a minimum of three months and that signed the informed consent form (ICF). Individuals that fulfilled one or more of the following criteria were excluded from the study: hemodynamic instability, amputation, deep vein thrombosis, severe dyspnea, femoral fistula, precordial pain, unstable angina, orthopedic impairments, musculoskeletal, neurological and /or cognitive changes that compromised participation in the study, and those individuals who refused to sign the ICF.

Initially, 40 patients were invited to participate in the study. Of these, 27 agreed to participate, with the refusals being due to unavailability of time and/or lack of interest. Overall, four additional losses were considered: two due to death and two withdrawals of the ICF. The study was approved by the Research Ethics Committee of the University of Passo Fundo (CAAE: 11781413.8.0000.5342) and by the Hospital in which the data was collected.

The clinical and anthropometric characteristics of the participants were verified through prior evaluation and analysis of the medical records, with the application of a questionnaire to verify the sociodemographic characteristics. To evaluate the RMS, maximal inspiratory pressure (MIP) and maximal expiratory pressure (MEP) were assessed using an analog respiratory pressure meter (Commercial Médica ${ }^{\circledR}$, support class model B-ABNT), calibrated in $\mathrm{cmH} 2 \mathrm{O}$ with operational limit of \pm 300 , prior to the start of the treatment, on the second day of dialysis. The MIP was measured from the residual volume (RV), while the MEP was measured from the total lung capacity (TLC).
All individuals performed the maneuvers three times for at least one to two seconds (10). For the analysis, using the equation of Neder et al. (1999), the highest values obtained for inspiration and expiration were used. These could not exceed the nearest value by more than $10 \%$, with the values obtained being compared with the predicted values for the Brazilian population.

The evaluation of the submaximal functional capacity (SMFC) was carried out through the 6-minute walk test (6MWT), according to the American Thoracic Society (11). In a flat 30 meter corridor, with markings every 3 meters, the patient was instructed to walk as quickly as possible, without slowing down, and to complete as many lengths as possible. The following variables were measured at the beginning and immediately after 6 minutes of the test: blood pressure (BP), heart rate (HR), respiratory rate (RR), oxygen saturation (SO2) and perceived exertion through the modified Borg scale (12). Every minute the patient was encouraged, through verbal commands, always by the same examiner, to walk as fast as possible.

The PF was evaluated by spirometry, using an MR spirometer (Spirodoc ${ }^{\circledR}$ model, Italy). Spirometric lung volumes, such as forced vital capacity (FVC), forced expiratory volume in one second (FEV1) and the Tiffeneau index (FEV1/FVC), were measured from the total lung capacity. Both tests were performed with the patient seated, and followed the recommendations of the Guidelines for Pulmonary Function Tests $(13,14)$.

The numerical variables were expressed as mean \pm standard deviation and median (percentile25 percentile75), according to whether they presented normal or non-normal distribution. The correlations between spirometric variables, RMS and SMFC, expressed as percentage of that predicted for age and gender, were evaluated using Pearson's linear correlation coefficient. Tests with p-values <. 05 were considered to be statistically significant.

\section{Results}

Of the 23 patients included in the study, all were male with a mean age of $50.2 \pm 15.8$ years. The median time of HD was 3 (1.5 to 6.0) years. Regarding smoking, 11 (47.8\%) reported never having smoked, $11(47.8 \%)$ to be ex-smokers and $1(4.3 \%)$ a current 
smoker. Among the former and current smokers, the median time of smoking was 25.0 (8.8 to 38.8) years. The majority were retired 15 (65.21\%), 13 $(56.52 \%)$ presented no complaints, however, some of the patients reported cramps - 4 (17.39\%), fatigue - 3 (13.04\%) and headaches - $3(13.04 \%)$. The etiological cause of higher incidence was hypertension - 9 (39.13\%), followed by diabetes mellitus - 5 (21.53\%) (Table 1).

Table 2 shows the predicted values and those obtained by the patients for RMS, PF and 6MWT. The mean MIP\% was $36.0 \pm 13.6$, MEP\% $49.5 \pm 15.8$, FVC $\% 93.8 \pm 21.1$, FEV1\% $93.7 \pm 21.1$, FEV1/FVC\% $104.1 \pm 10.3$, and $6 \mathrm{MWT} \% 66.33 \pm 20.53$.

Table 3 describes the correlations between spirometric variables, RMS and SMFC expressed as a percentage of that predicted for age and gender.

There was a statistically significant positive correlation between the 6MWT and MIP $(r=.63, p=.001)$ and MEP $(r=.67, p<.001)$. There was no statistically significant association between the 6MWT and FVC ( $\mathrm{r}=.22, \mathrm{p}=.317)$, FEV1 ( $\mathrm{r}=.09, \mathrm{p}=.674)$ and FEV1/ $\mathrm{FVC}(\mathrm{r}=-0.26, \mathrm{p}=.234)$.

There was a significant correlation between MIP and MEP ( $\mathrm{r}=.79, \mathrm{p}<.001)$ and between FEV1 and FVC $(\mathrm{r}=.91, \mathrm{p}<.001)$.

Table 1- Sociodemographic and clinical characteristics

\begin{tabular}{lcc}
\hline \multicolumn{1}{c}{ Age (years) } & $\mathbf{5 0 . 2} \pm \mathbf{1 5 . 8}$ \\
\hline $\begin{array}{l}\text { Time of HD } \\
\text { (years) } \\
\text { Smoking }\end{array}$ & $3(1.5-6.0)$ \\
& Never smoked & $11(47.8)$ \\
& Ex-smoker & $11(47.8)$ \\
& Smoker & $1(4.3)$ \\
Time of smoking & & $25(8.8-38.8)$ \\
(years) & Retired & $15(65.21)$ \\
Occupation & Unemployed & $8(34.78)$ \\
& DM & $5(21.73)$ \\
& & $9(39.13)$ \\
& Stiological cause &
\end{tabular}

Table 1- Sociodemographic and clinical characteristics (Conclusion)

\begin{tabular}{ccc}
\hline Age (years) & & $\mathbf{5 0 . 2} \pm \mathbf{1 5 . 8}$ \\
\hline & Glomerulonephritis & $5(21.73)$ \\
& UTO + SH & $2(8.69)$ \\
Main complaint & None reported & $13(56.52)$ \\
& Cramps & $4(17.39)$ \\
& Fatigue & $3(13.04)$ \\
Headaches & $3(13.04)$ \\
Comorbidities & DM & $2(8.69)$ \\
& SH & $8(34.78)$ \\
& DM+SH & $6(26.08)$ \\
& None reported & $7(30.43)$ \\
\hline
\end{tabular}

Note: HD Hemodialysis; DM - Diabetes Mellitus; SH - systemic hypertension; UTO - Urinary tract obstruction; Values as mean \pm standard deviation; Absolute value(\%); Time of HD and smoking as median (minimum value-maximum value).

Table 2 - Characteristics of the predicted and obtained data

\begin{tabular}{lcc}
\hline & Predicted & Obtained $(\% \pm$ SD) \\
\hline MIP (cmH20) & 197.2 & $36.0 \pm 13.6$ \\
MEP (cmH20) & 207.4 & $49.5 \pm 15.8$ \\
FVC (I/min) & 3.9 & $93.8 \pm 21.1$ \\
FEV1 (l/min) & 3.11 & $93.7 \pm 21.1$ \\
FEV1/FVC (1/min) & 76.8 & $104.1 \pm 10.3$ \\
6MWT (m) & 711.2 & $66.33 \pm 20.53$
\end{tabular}

Note: MIP - maximum inspiratory pressure; MEP - maximal expiratory pressure; FVC - forced vital capacity; FEV1 - Forced expiratory volume in one second; FEV1/FVC - Tiffeneau Index; 6MWT - 6-minute walk test. 
Table 3- Correlations between spirometric variables, RMS and SMFC expressed as a percentage of that predicted for age and gender $(n=23)$

\begin{tabular}{l|c|c|c|c|c|c}
\hline \multicolumn{2}{c}{ MIP } & \multicolumn{2}{c}{ MEP } & \multicolumn{2}{c}{ FVC } & \multicolumn{2}{c}{ FEV1 } & \multicolumn{2}{c}{ FEV1/FVC } & 6MWT \\
\hline \multirow{3}{*}{ MIP } & - & $r=.79$ & $r=.11$ & $r=-.03$ & $r=-.03$ & $r=.63$ \\
\cline { 2 - 7 } & & $p<.001$ & $p=.618$ & $p=.880$ & $p=.160$ & $P=.001$ \\
\hline \multirow{2}{*}{ MEP } & & - & $r=-.01$ & $r=-.16$ & $r=-.28$ & $r=.67$ \\
\cline { 2 - 7 } & & & $p=.964$ & $p=.475$ & $p=.204$ & $p<.001$ \\
\hline \multirow{2}{*}{ FVC } & & & - & $r=.91$ & $r=-.23$ & $r=.22$ \\
\hline \multirow{2}{*}{ FEV1 } & & & & $p<.001$ & $p=.287$ & $p=.317$ \\
\cline { 2 - 7 } & & & & - & $r=.18$ & $r=.09$ \\
\hline \multirow{2}{*}{ FEV1/FVC } & & & & & $p=.400$ & $p=.674$ \\
\cline { 2 - 7 } & & & & & - & $r=-.26$ \\
\hline
\end{tabular}

Note: MIP: maximal inspiratory pressure; MEP: maximal expiratory pressure; FVC: forced vital capacity; FEV1: forced expiratory volume in one second; FEV1/FVC: Tiffeneau index; 6MWT: 6-minute walk test

\section{Discussion}

The etiological cause of higher incidence among patients with terminal CKD in this study was SH followed by DM, as confirmed in other studies with large population bases, in which, among adults that developed CKD, the vast majority of cases ( $>70 \%$ ) were due to these pathologies $(15,16)$. A large body of evidence from clinical trials and epidemiological studies indicates that hypertension is a major risk factor for CKD (17). In one study, more than 330,000 men were monitored over a period of 16 years, in which, the initial BP was quantitatively presented as a predictor of risk for CKD, with a twofold increase in risk, even among men with BP within the normal range of values (18). In observational studies, it was found that the relationship between BP and progression of CKD is direct and progressive (19).

Recent studies suggest that CKD affects approximately $30 \%$ of patients with type $1 \mathrm{DM}$ and $20 \%$ of patients with type $2 \mathrm{DM}(20)$. The time from diagnosis of the disease is another risk factor for the development of CKD, even though prevalence studies are difficult to interpret (21). It is estimated that in the United Kingdom approximately one third of patients with CKD developed the disease due to DM (22). Men seem to be at greater risk of developing nephropathy than women $(23,24)$, as shown in the present study, where all the individuals who agreed to participate were male.

Despite a general improvement in care for the risk factors such as hypertension, diabetes mellitus and smoking, the proportion of Americans with CKD has been mainly attributed to the aging of the population (16). In adults over 40 years, the glomerular filtration rate decreases by about $1 \%$ per year and older adults have higher rates of $\mathrm{DM}, \mathrm{SH}$ and other risk factors for CKD (25). As noted in the present study, the population was constituted by adults of average age and elderly people, of whom almost half had smoked in the past and one individual still smoked.

The study showed, as one of the main results, correlation between RMS and SMFC. Overall, the patients presented a decrease in RMS of $<70 \%$ of that predicted (26). The results also showed that the majority of the patients presented spirometric values within normal limits (13).

The muscles responsible for respiration, such as the diaphragm and intercostals, among others, are classified as skeletal muscles and may present decreased strength and muscle endurance properties resulting from uremic myopathy. Some authors have studied the impairment of uremia in the diaphragm and concluded that there is loss of strength with severe uremia. The ventilatory deficit resulting from this compromise in the respiratory muscles, combined with other lung tissue compromises, impairs the function of this system, contributing to decreased lung capacity $(27,28)$. 
Since the measures of MIP and MEP are easily obtained, and taking into account that the values allow a relatively precise evaluation of the functional status of the respiratory muscles, it would be important to assess not only the degree of impairment at baseline, but also the influence of the hemodialysis session (9).

In the study by Dipp et al., patients showed a reduction of MEP and 6MWD compared to the predicted values, representing, respectively, expiratory muscle weakness and decreased functional capacity, which is in agreement with the present study. This finding may be explained by the occurrence of uremic myopathy that intensely alters the skeletal muscular system, changing the type I and type II muscle fibers, especially those of type II (29).

In the present study, the presence of a significant correlation between MIP and MEP allows the assumption that one is dependent on the other and, when one value is lower than that predicted, the other will follow this trend.

In a study by Moreira and Barros, with patients undergoing dialysis, muscle strength was decreased by $30 \%$ to $40 \%$ compared to normal subjects, which was related to structural and metabolic changes (30). For Vieira et al., the etiology of muscle weakness is multifactorial, however, the main cause is vitamin D deficiency (31). Studies with terminal CKD individuals have demonstrated RMS and the PF variables below the normal range (32). In the present study, only the RMS values were found to be lower than expected (MIP\% $36.0 \pm 13.6$, MEP\% $49.5 \pm 15.8$ ), as was the case in the study of Jatobá et al., in which the MIP and MEP were found to be $38.2 \%$ and $29 \%$ below the minimum expected values, respectively (33).

Individuals with CKD, when compared to healthy subjects, present pulmonary disorders, such as decreased airflow, obstructive disorders, reduced lung diffusion capacity, and decreased strength and RMS (33-35).

Reduced distance covered in the 6MWD was verified in this sample of patients, compared to that predicted by the equations of Enright and Sherrill for normal subjects $(6 \mathrm{MWT} \% 66.33 \pm 20.5)$. Low cardiorespiratory fitness and functional capacity are associated with increased risk of mortality, hospitalization and morbidity in CKD patients $(36,37)$. In the study of Baumgarten et al., functional capacity was measured through the 6MWT, with a decrease of approximately $28 \%$ in the distance covered in relation to the predicted values ( $387.8 \pm 100.1$ vs. 544.9 \pm 104.9; p <.001) (38).

In the present study, a statistically significant positive correlation was observed between the 6MWT and MIP ( $\mathrm{r}=.63, \mathrm{p}=.001)$, which shows that performance in the 6MWT is proportional to that found in relation to inspiratory muscle strength. A similar result was found by Jatobá et al. $(r=.39, \mathrm{p}=.04)$ (33).

Exercise intolerance is an essential clinical aspect in a wide range of diseases, including CKD, and is closely associated with deterioration in the quality of life and increased morbidity and mortality, due to cardiovascular disease. Patients with CKD undergoing HD present low exercise tolerance and deconditioning, despite advances in dialysis procedures.

Muscular weakness is a complication of CKD and the loss of muscle mass is the most significant predictor of mortality in patients undergoing HD (39). Furthermore, longer periods of HD treatment are associated with decreased RMS (40). The symptoms of muscle involvement translate into fatigue, weakness, atrophy, irritability and cramps (41). In patients with chronic renal failure requiring HD, RMS and PF are directly linked to their body mass index, especially when associated with a longer HD treatment period and with the period between sessions (40). Individuals with CKD, when compared to healthy subjects, present pulmonary disorders, such as decreased airflow, obstructive disorders, reduced lung diffusion capacity, and decreased strength and RMS (33-35).

\section{Conclusion}

Individuals with CKD undergoing HD present changes in respiratory muscle strength, with decreasing values for gender and age, as well as in the distance covered in the 6MWD, however, with spirometric values within normal limits. Functional capacity was found to be dependent on respiratory muscle strength, as well as the values of MIP and MEP and the values of FVC and FEV1. When one value decreased, the other followed this trend. Despite advances in dialysis procedures, these patients show low exercise tolerance, which leads to physical deconditioning and poor health related quality of life. 


\section{References}

1. WHO - World Health Organization. Non communicable Diseases: Country Profiles. Geneva; 2011.

2. Bastos MG, Kirsztajn GM. Doença renal crônica: importância do diagnóstico precoce, encaminhamento imediato e abordagem interdisciplinar estruturada para melhora do desfecho em pacientes ainda não submetidos à diálise. J Bras Nefrol. 2011; 33(1):93-108.

3. Kusumoto, L, Marques S, Hass, VJ, Rodrigues RAP. Adultos e idosos em hemodiálise: avaliação da qualidade devida relacionada à saúde. Acta Paul Enferm. 2008; 21(Especial):152-9.

4. Machado LRC, Car MR. A dialética da vida cotidiana de doentes com insuficiência renal crônica: o inevitável e o casual. Rev Esc Enferm USP. 2003; 37(3):27-35.

5. Terra FS, Costa AMDD, Figueiredo ET, Morais AM, Costa MD, Costa RD. As principais complicações apresentadas pelos pacientes renais crônicos durante as sessões de hemodiálise. Rev Bras Clin Med 2010; 8(3):187-92.

6. Cunha MS, Andrade V, Guedes CAV, Meneghetti CHZ, Aguiar AP, Cardoso AL. Avaliação da capacidade funcional e da qualidade de vida em pacientes renais crônicos submetidos a tratamento hemodialítico. Fisioter Pesq. 2009; 16(2): 155-60.

7. Oh-Park M, Fast A, Gopal S, Lynn R, Frei G, Drenth R, et al. Exercise for the dialyzed. Aerobic and streng training during hemodialysis. Am J Phys Med Rehabil. 2002; 81(11): 814-21.

8. Pellizzaro CO, Thomé FS, Veronese FV. Effect of peripheral and respiratory muscle training on the functional. Ren Fail. 2013; 35(2): 189-97.

9. Rocha CBJ, Araújo S. Avaliação das pressões respiratórias máximas em pacientes renais crônicos nos momentos pré e pós hemodiálise. J Bras Nefrol. 2010; 32(1): 107-13.

10. Neder JA, Andreoni S, Lerario MC, Nery LE. Reference values for lung function tests. II. Maximal respiratory pressures and voluntary ventilation. Braz J Med Biol Res. 1999; 32(6): 719-27.

11. American Thoracic Society. ATS Statement: Guidelines for the Six-Minute Walk Test. Am J Respir Crit Care Med. 2002; 166: 111-7.
12. Wilson RC, Jones PW. A comparison of the visual analogue scale and modified Borg scale for the measurement of dyspnea during exercise. Clin Sci. 1989; 76(3): 277-82.

13. Pereira CAC. Espirometria. J Pneumol. 2002; 8:S1-82.

14. Souza RB. Pressões respiratórias estáticas máximas. J Pneumol. 2002; 28: S155-65.

15. National chronic kidney disease fact sheet. Atlanta (GA): Centers for Disease; 2014 [cited 2015 Sept]. Available from: http://www.cdc.gov/diabetes/pubs/ pdf/kidney_factsheet.pdf.

16. Kiefer MM, Ryan MJ. Primary Care of the Patient with Chronic Kidney Disease. Med Clin North Am. 2015; 99(5): 935-52.

17. Schaefer F, Mehls O. Hypertension in chronic kidney disease. In: Portman RJ, Sorof JM, Ingelfinger JR, editors. Pediatric hypertension. Totowa: Humana Press; 2004. p. 371- 87.

18. Klag MJ, Whelton PK, Randall BL, et al. Blood pressure and end-stage renal disease in men. Hypertension. 1996; 13:180-93.

19. Gansevoort RT, Correa-Rotter R, Hemmelgarn BR, Jafar TH, Heerspink HJ, Mann JF, et al. Chronic kidney disease and cardiovascular risk: epidemiology, mechanisms, and prevention. Lancet. 2013; 382(9889): 339-52.

20. American Diabetes Association. Nephropathy in Diabetes. Diabetes Care. 2004; 27(Suppl 1):S79-S83.

21. Eboh C, Chowdhury TA. Management of diabetic renal disease. Ann Transl Med. 2015; 3(11):154.

22. Liew BS, Perry C, Boulton-Jones JM, Simpson K, Paterson K. Diabetic nephropathy: an observational study on patients attending a joint diabetes renal clinic. QJM. 1997; 90(5): 353-8.

23. Burden AC, McNally PG, Feehally J, Walls J. Increased incidence of end stage renal failure secondary to diabetes mellitus in Asian ethnic groups in the United Kingdom. Diabet Med. 1992; 9(7): 641-5.

24. Cowie CC, Port FK, Wolfe RA, Savage PJ, Moll PP, Hawthorne VM. Disparities in incidence of diabetic end stage renal disease according to race and type of diabetes. N Engl J Med. 1989; 321:1074-9. 
25. Hoyert D, Xu J. Deaths: Preliminary data for 2011. National Vital Statistics Reports, vol. 61. Hyattsville (MD): National Center for Health Statistics; 2012 [cited 2015 Sept]. Available from: ttp://www.cdc.gov/ nchs/data/nvsr/nvsr61/nvsr61_06.pdf.

26. Dall'Ago P, Chiappa GR, Guths H, Stein R, Ribeiro JP. Inspiratory muscle training in patients with heart failure and inspiratory muscle weakness: a randomized trial. J Am Coll Cardiol. 2006; 47(4): 757-63.

27. Kemp GJ, Crowe AV, Anijeet HK, Gong QY, Bimson WE, Frostick SP, et al. Abnormal mitochondrial function and muscle wasting, but normal contractile efficiency, in haemodialysed patients studied non-invasively in vivo. Nephrol Dial Transplant. 2004; 19(6): 1520-7.

28. Sakkas GK, Sargeant AJ, Mercer TH, Ball D, Koufaki $\mathrm{P}$, Karatzaferi $\mathrm{C}$ et al. Changes in muscle morphology in dialysis patients after 6 months of aerobic exercise training. Nephrol Dial Transplant. 2003; 18(9): 1854-61.

29. Dipp T, Silva AMV, Signori LU, Strimbam TM, Nicolodi G, Sbruzzi G. et al. Força muscular respiratória e capacidade funcional na insuficiência renal terminal. Rev Bras Med Esporte. 2010; 16(4): 246-49.

30. Moreira PR, Barros EG. Revisão/Atualização em Diálise: capacidade e condicionamento físico em pacientes mantidos em hemodiálise. J Bras Nefrol. 1998; 20(2): 207-210.

31. Vieira WP, Gomes KWP, Frota NB, Andrade JEBA, Vieira RMRA, Moura FEA, et al. Manifestações musculoesqueléticas em pacientes submetidos à hemodiálise. Rev Bras Reumatol. 2005; 45(6): 357-64.

32. Coelho CC, Aquino ES, Lara KL, Peres TM, Barja PR, Lima EM. Repercussões da insuficiência renal crônica na capacidade de exercício, estado nutricional, função pulmonar e musculatura respiratória de crianças e adolescentes. Rev Bras Fisioter. 2008; 12(1): 1-6.

33. Jatobá JPC, Amaro WF, Andrade APA, Cardoso FPF, Monteiro AMH, Oliveira, MAM. Avaliação da função pulmonar, força muscular respiratória e teste de caminhada de seis minutos em pacientes portadores de Doença Renal Crônica em hemodiálise. J Bras Nefrol. 2008; 30(4): 280-7.
34. Karacan O, Tutal E, Colak T, Sezer S, Eyüboğlu FO, Haberal M. Pulmonary function in renal transplant recipients and end-stage renal disease patients undergoing maintenance dialysis. Transplant Proc. 2006; 38(2): 396-400.

35. Schardong TJ, Lukrafka JL, Garcia VD. Avaliação da função pulmonar e da qualidade de vida em pacientes com doença renal crônica submetidos à hemodiálise. J Bras Nefrol. 2008; 30(1): 40 - 7.

36. Sietsema KE, Amato A, Adler SG, Brass EP. Exercise capacity a predictor of survival among ambulatory patients with end stage renal disease. Kidney Int. 2004; 65(2): 719-24.

37. Knight EL, Ofsthun N, Teng M, Lazarus JM, Curhan GC. The association between mental health, physical function, and hemodialysis mortality. Kidney Int. 2003; 63(5): 1843-51.

38. Baumgarten MCS, Dipp T, Silva VG, Giacomazzi CM, Segatto K, Pereira GA, et al. Percepção subjetiva e desempenho físico de pacientes com doença renal crônica em hemodiálise. Rev. Acta Bras Mov Hum. 2012; 2(1): 5-14.

39. Cheema BS, Smith BC, Singh MA. A rationale for intradialytic exercise training as standard clinical practice in ESRD. Am J Kidney Dis. 2005; 45(5): 912-6.

40. Kovelis D, Pitta F, Probst VS, Peres CPA, Delfino VDA, Mocelin AJ,et al. Função pulmonar e força muscular respiratória em pacientes com doença renal crônica submetidos à hemodiálise. J Bras Pneumo. 2008; 34(11): 907-12.

41. Riella MC, Pecoits-Filho, R. Insuficiência renal crônica: fisiopatologia da uremia. In: Riella MC. Princípios de nefrologia e distúrbios hidroeletrolíticos. Rio de Janeiro: Guanabara Koogan; 2003. p. 661-8.

Receveid: 11/02/2013 Recebido: 02/11/2013

Approved: 09/30/2015 Aprovado: 30/09/2015 